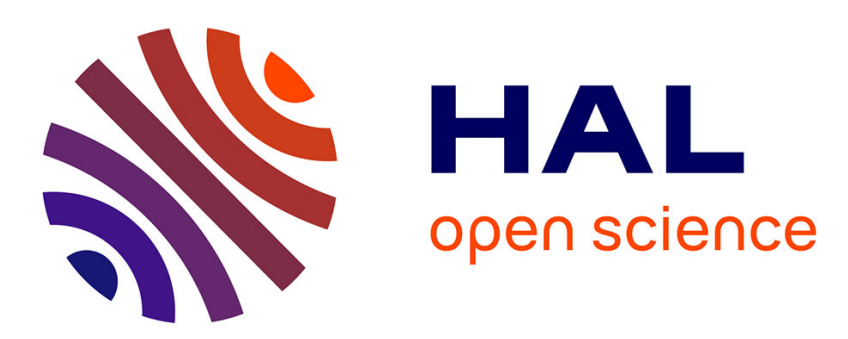

\title{
Decolonizing regional planning from the Global South: Active geographies and social struggles in Northeastern Brazil
}

\author{
Federico Ferretti
}

\section{- To cite this version:}

Federico Ferretti. Decolonizing regional planning from the Global South: Active geographies and social struggles in Northeastern Brazil. Environment and Planning D: Society and Space, 2021, pp.026377582110246. 10.1177/02637758211024647 . hal-03269544

HAL Id: hal-03269544

https://hal.science/hal-03269544

Submitted on 24 Jun 2021

HAL is a multi-disciplinary open access archive for the deposit and dissemination of scientific research documents, whether they are published or not. The documents may come from teaching and research institutions in France or abroad, or from public or private research centers.
L'archive ouverte pluridisciplinaire HAL, est destinée au dépôt et à la diffusion de documents scientifiques de niveau recherche, publiés ou non, émanant des établissements d'enseignement et de recherche français ou étrangers, des laboratoires publics ou privés. 
Prof FEDERICO FERRETTI - BA, MA, PhD, Professore Ordinario di Geografia/Full Professor of Geography, Alma Mater Studiorum Università di Bologna, Dipartimento di Scienze dell'Educazione “G.M. Bertin”, Studio 70, Via Filippo Re 6, 40126 Bologna, Italy federico.ferretti6@unibo.it $\quad+39 \quad 051 \quad 2091609$ https:/www.unibo.it/sitoweb/federico.ferretti6 ORCID ID: 0000-0002-5446-6522; Scopus ID: 55540917000

\section{Decolonizing regional planning from the Global South: active geographies and social struggles in Northeastern Brazil}

Abstract: This paper addresses the engagement of critical geographers from Northeastern Brazil with regional planning, aiming at transforming society by acting on their region's spaces. Extending and putting in relation literature on planning theory in the Global South and geographical scholarship on decoloniality, I explore new archives showing how the planning work that these geographers performed from 1957 to 1964 was an example of the 'South' reelaborating and putting into practice notions arising from 'international' literature, such as that of 'active geography', and pioneering critical uses of instruments, such as mappings and statistics, that have often been associated with technocracy and political conservatism. Connected with peasants' struggles and with a theoretical framework that is cognisant of the colonial histories and insurgent Black and indigenous traditions in the Northeast, these geographers' works show that there is no 'Southern Theory' without a concrete engagement of scholars with social and political problems, one which is not limited to 'participation', but aims at challenging the political powers in place. Although not devoid of contradictions that are analysed here, the experiences of these Southern geographers acting in and for the South can provide precious insights into current (Northern or Southern) scholarly programmes aimed at resisting oppression.

Keywords: Decolonizing Social Theory; Northeastern Brazil; Regional Planning; River Basin; Active Geography

F. Ferretti, 2021, "Decolonizing regional planning from the Global South: active geographies and social struggles in North-eastern Brazil", Environment and Planning D - Society and Space, early view https://journals.sagepub.com/doi/full/10.1177/02637758211024647 
This paper extends current debates on the decolonization of social theory and practices by addressing a virtually unknown case in the social commitment of geographers to societal transformation through regional planning in the Global South. This story took place in the Northeast of Brazil, which was traditionally considered as the poorest and most 'underdeveloped' part of the country (Castro 1969). Being aware that, as John Glasson and Tim Marshall point out, "there is no such thing as an abstract "correct" definition of planning valid for any place or time' (Glasson and Marshall 2007, 4), I analyse the multiple endeavours carried out between 1957 and 1964 by a network of geographers to build ideas of regional planning. Among these Northeastern (mainly Pernambucan) scholars, I shall mention Manuel Correia de Andrade (1922-2007), Gilberto Osório de Andrade (1912-1986), Mário Lacerda de Melo (1913-2004), Mauro Mota (1911-1984) and Rachel Caldas Lins, who collaborated with the most prestigious intellectuals of their region such as Gilberto Freyre (1900-1987), geographers Josué de Castro (1908-1973) and Milton Santos (1926-2001), writer and political activist Francisco Julião (1915-1999) and economist Celso Furtado (1920-2004). Born in the state of Paraíba, Furtado was the founder of the SUDENE (Superintendência do Desenvolvimento do Nordeste), a governmental organism initially designed to foster 'regional development' through planning in the Northeast. The SUDENE was supported by the scholars mentioned above (all 'canonised' academic geographers except Julião and Furtado), who first argued for the pressing need of social reforms in the region. This was a rupture with a long tradition of efforts to find technocratic solutions for the dreadful effects of the periodical droughts and famines affecting the Northeast. Technocrats drew upon positivistic assumptions that these phenomena had 'natural' rather than social causes, fostering racial and civilisational blame of Northeasterners' 'backwardness' (Buckley 2017).

Exploring original works and unpublished archival materials of these critical geographers, especially the archives of Santos and Correia de Andrade surviving at the São Paulo IEB (Instituto de Estudos Brasileiros) and those of Castro, Mota and Julião at the Recife CEHIBRA (Coordenação-Geral de Estudos da História Brasileira) in the Fundação Joaquim Nabuco, I show their engagement with regional planning and extend Brazilian scholarship, which challenges commonplaces pretending that the field of 'critical geography' was extraneous to the allegedly more conservative field of 'planning' (Pedrosa 2013 and 2017). Indeed, scholars

F. Ferretti, 2021, "Decolonizing regional planning from the Global South: active geographies and social struggles in North-eastern Brazil", Environment and Planning D - Society and Space, early view https://journals.sagepub.com/doi/full/10.1177/02637758211024647 
such as Santos, Castro and Andrade, who always considered themselves as 'geographers' rather than 'planners', engaged with experiences in planning, deeming this relevant for the construction of a Brazilian 'active (i.e., critical and socially engaged) geography'.

Their ideas on planning stemmed directly from their theorisation of regions as entities intrinsically linked to the respective cities. Such concepts recall French regional geography (Castro 1959; Santos 1959) and a longer tradition in so-called 'organic planning', rejecting a rigid distinction between the 'city' and the 'countryside', coming back to Patrick Geddes and to anarchist geographers Elisée Reclus and Pyotr Kropotkin (Pesce 1981), authors who were well known by Brazilian critical geographers (Ferretti, 2019a). Therefore, my definition of 'regional planning' is referred to this tradition, with the important consideration that the SUDENE explicitly adopted the same label, that is Planejamento Regional (Buckley 2017). Yet, these Brazilian scholars cannot be considered as mere interpreters of 'northern' theories, because they re-elaborated and put into practice these ideas in original ways, drawing upon social and cultural particularities of their land. Recent international scholarship which is rediscovering works of Santos, Andrade and Castro shows that they produced an internationally influential output in matters such as underdevelopment, dependency and critical geopolitics, criticising Northern recipes for 'development' (Davies 2019a, 2019b and 2019c; Ferretti and Pedrosa 2018; Melgaço 2017). Politically, their work proved to be so prickly for the power in place that, after the 1964 coup, the Brazilian military dictatorship stopped their endeavours and banished, imprisoned or marginalised most of them (Ferretti 2018).

Extending scholarship by Ananya Roy (2006), Katharine N. Rankin argues that liberal and paternalistic ideas of planners' 'responsibility' should be replaced by a postcolonial ethics of 'accountability', which first means 'a commitment to recovering the perspectives and voices of marginalised, oppressed and dominated people' (Rankin 2010, 182). This implies acknowledging the notion of imperialism, the past and present implications of geography and planning with colonial practices, and a reflection on the value of differences rather than the exportation of given models from the European and North-American 'core' to the 'periphery'. For Rankin, researchers should consider their positionality prior to propose any 'enlightened' recipe to tell other people what to do, while postcolonial critiques should pay attention to

F. Ferretti, 2021, "Decolonizing regional planning from the Global South: active geographies and social struggles in North-eastern Brazil", Environment and Planning D - Society and Space, early view https://journals.sagepub.com/doi/full/10.1177/02637758211024647 
'planning's complicity in the material and discursive processes that constitute the global South in a dependent, inferior and racialized relationship to the global North' (Rankin 2010, 194). Roy also criticizes the numerous 'examples of a homegrown neoliberalization, one produced to consolidate postcolonial sovereignty and territory' (Roy 2011, 10). This chimes with recent scholarship on subaltern geographies noticing how 'theorizing from the South should be conceived less as the simple inversion of a more established geography of (theoretical) knowledge production and more as an "epistemological disruption"” (Jazeel and Legg 2019,4) reverting Eurocentric methodologies. Likewise, postcolonial scholarship claims for acknowledging 'other postcolonialisms' (Sidaway, Woon and Jacobs 2014). The experiences of Brazilian critical geographies can provide precious insights into the possible openings and limitations of these strategies.

Global South geographical scholarship is increasingly committed to participation and engagement with marginalised communities, inspired by feminist approaches that question the authoritative and universal gaze of Western researchers. While issues concerning decolonizing geography (knowledges and praxes) are widely debated (Radcliffe 2017; Esson et al., 2017; Noxolo 2017), encounters with Latin American knowledge are increasingly acknowledged by international scholarships as inspirations (Halvorsen 2018), especially around works of the Modernity-Coloniality-Decoloniality (MCD) collective (Mignolo and Escobar 2010; Mignolo and Walsh 2018). This paper extends this literature, including recent works on postdevelopment, classically arguing for the failure of the very notion of development (Sachs 1992) and recently addressing it as a geopolitical device for neo-colonial powers during the Cold War (Power 2019). An important concept which informs post-development and MCD authors is the 'pluriverse', defined as, following the Zapatistas, 'a world where many worlds fit' (Kothari et al. 2019, Xxviii). Adopting heterogeneous and cosmopolitan approaches as I explain below, Northeastern geographers anticipated some aspects of this plurality. Their early engagement with concrete problems of Northeastern subalterns provides original contributions to current critical scholarship which addresses places and praxes of social movements (Halvorsen, Fernandes and Torres 2019; Souza 2016).

F. Ferretti, 2021, "Decolonizing regional planning from the Global South: active geographies and social struggles in North-eastern Brazil", Environment and Planning D - Society and Space, early view https://journals.sagepub.com/doi/full/10.1177/02637758211024647 
While decoloniality does not necessarily equate with 'Southern Theory', I consider these as related and complementary sets of ideas. In the field of planning, 'Southern Theory' has been defined by Raewyn Connell as a challenge to the idea that there should be a dependent periphery supplying the data, and a 'core' producing theories to analyse them within a 'northern-centred economy of knowledge' (Connell 2014, 214). However, as Connell notes, defining what 'Southern Theory' might look like is extremely complicated: this recalls David Slater's arguments about the multiple ways in which the South 'theorised back' (Slater 1993). For Slater, the construction of dependentist theories, which included economists like Furtado and geographers such as Santos and Castro (Ferretti and Pedrosa 2018), was an endeavour where subalterns 'not only speak, act and write back. [Dependentist theories] form an intrinsic part of the globality of knowledge' (Slater 2004, vii). These difficulties in defining a unique and consistent 'Southern Theory' do not undermine the importance of rediscovering these experiences to foster decolonial agendas, given that it is exactly the plurality and complexity of the knowledges and practices that were produced or re-elaborated in the Souths that can nourish current debates, as I discuss below.

The Northeast of Brazil was heavily affected by plantation slavery since colonial times, and a wide range of social movements from early peasants' leagues to the Movimento dos Trabalhadores Rurais Sem Terra (Zibechi 2012) has claimed continuity with the history of insurgent indigenous and Afro-Brazilian communities characterizing the region. Conversely, many scholars have exposed the difficulties of 'Western-minded' professionals in approaching indigeneity, as exposed by Libby Porter about an Australian case (Porter 2006). There, the author argues that planning policies have failed in preparing 'planners to productively engage with Indigenous people ... overcoming the barriers of the links between research and practice' (Porter 2017, 557) and in providing accountability for the responsibility of the colonizers in the massacre and spoliation of the first peoples. Commenting on a South-African project performed by scholars who adamantly acted to 'defend' a local community, Tanja Winkler further exposes the challenges of working across different cultures, pointing on the differences existing between the respective mindsets of the community members and of the external researchers, which eventually led to persisting misunderstandings. This suggests that one should avoid reducing all debates to a single thought, and embrace decolonial claims 'towards

F. Ferretti, 2021, "Decolonizing regional planning from the Global South: active geographies and social struggles in North-eastern Brazil", Environment and Planning D - Society and Space, early view https://journals.sagepub.com/doi/full/10.1177/02637758211024647 
appreciating pluri-versal, as opposed to uni-versal, knowledge claims' (Winkler 2018, 590), exposing how planning theories and actions are never neutral and need 'meta-ethical questionings' (Winkler and Duminy 2016). Below, I show how considering scholars' practices and links to grassroots movements can help in shedding some light into these questionings.

My argument is twofold. First, I contend that the work of Northeastern geographers was the specific Brazilian contribution to ideas of 'active geography', intended as synonymous with socially and politically relevant geography, that they re-elaborated and put into practice, also through regional planning. Endogenous attempts to change society like those that inspired the early SUDENE provided relevant critiques to neo-colonial and Malthusian recipes for development coming from the North. Their promoters contributed to social movements, such as peasants' leagues, and paid attention to the region's histories of subaltern insurgency, criticising internal colonialism and arguing for including environmental concerns in radical social practices. Furthermore, these socially-engaged scholars from Northeastern Brazil pioneered the critical use of 'quantitative' research tools such as mappings, surveys and statistics, whose subversive potentialities were only recognized later by most (Northern and Southern) scholars, as such methods were often associated with technocracy and political conservatism (Buttimer 1974; Bunge 1988), including in Brazil (Pedrosa 2013 and 2017).

Second, these geographers' emphasis on praxes contributes to current decolonial and 'SouthSouth' debates by exposing the need for intellectuals to engage in socially transformative endeavours where scholarship is not only 'participative', but also activist, challenging the powers in place. As discussed by several contributors to Fiddian-Qasmiyeh's and Daley's Handbook on South-South Relations (2019), there is no such thing as a pure or uncontaminated 'Southern Theory' completely delinked from 'Northern' cultures. Scholars cannot neglect tracing sets of transcultural ideas and practices that circulate through different languages and places, addressing mobilities of knowledge, differences and contaminations to avoid monolingualism, provincialism and parochialism. Language also matters, as noticed by Amber Murrey arguing that: "“Theory from the South" is restricted by the continued predominance of the English language' (Murrey 2019, 67). The cases of cultural transferors such as Furtado, Castro, Santos and Andrade show the performance of multilingualism in circulating critical

F. Ferretti, 2021, "Decolonizing regional planning from the Global South: active geographies and social struggles in North-eastern Brazil", Environment and Planning D - Society and Space, early view https://journals.sagepub.com/doi/full/10.1177/02637758211024647 
ideas worldwide. As intellectuals from the South and working for the South, they engaged with 'Northern' knowledge to adapt and re-appropriate intellectual tools to fight injustice, putting (critical) theory into (activist) practice and building important premises to the 'pluriverse', which potentially help current scholarship to avoid essentialisations and generalisations on the notions of North and South.

This also confirms that the Global North-Global South divide, wherever one decides to locate it, cannot serve to elude issues on power and social justice within the Souths, also considering the slipperiness of the very concept of South-South cooperation, often suspected of creating new regional imperialisms (Fiddian-Qasmiyeh and Daley 2019). In the years preceding the 1964 coup, geographical and planning surveys carried out in Northeastern Brazil questioned for the first time the privileges of the landowning elites, showing that technocracy is not sufficient to resolve social problems. Albeit defeated, this attempt should inform current scholarship challenging what MCD authors call the 'coloniality of power' (Mignolo 2007).

Yet, the experiences of the scholars whose story is told here do not come without scrutiny, as their works present contradictions and ambivalences that cannot be ignored. These are related to the specific colonial situations of Brazil and its Northeast, which do not necessarily match analytical categories on settler colonialism that were mostly conceived addressing NorthAmerican cases. In Brazil, the distinction between white European settlers, indigenous and Afro-descendants, although importantly inspiring critiques of internal colonialism and extractivism (Porto-Gonçalves and Araújo Quental 2012), is further complicated by ideas of hybridity and miscegenation. Inspired by classical Luso-Tropicalism of Pernambucan sociologist Gilberto Freyre, these notions are currently criticized for hiding a reality of discrimination and racialized violence which renders the pretention of having accomplished 'racial democracy' in Brazil simply delusional (Schwarcz and Gomes 2018). Yet, these discussions should be considered to understand the complex positionality of Brazilian progressive intellectuals in a country which is ridden by contradictions that are not only related to race, class and gender but also to huge regional differences and disparities.

F. Ferretti, 2021, "Decolonizing regional planning from the Global South: active geographies and social struggles in North-eastern Brazil", Environment and Planning D - Society and Space, early view https://journals.sagepub.com/doi/full/10.1177/02637758211024647 
The Northeast has striking peculiarities, being the region where Afro-Brazilian legacies are most strongly perceived and where the political Left is most stably rooted in local governments. There, the idea of being 'internally colonialised' by the South of Brazil was also shared by progressive elites. As Castro claimed: 'The Northeast is a colony of the South [of Brazil], which is a colony of the United States, as in the past Brazil was a colony of Portugal, which was a colony of England', ${ }^{1}$ expressing the complex and multi-layered aspects of his land's colonial history and confirming the impossibility of considering the South as a 'pure' place to be opposed in a Manichean way to an equally idealised North. In this context, one can understand the ambivalences of intellectuals such as Castro, Andrade and Furtado. Although members of intellectual elites, they shared languages, experiences and places of marginalised communities and cannot be equated to colonial surveyors coming on a territory from outside to study local people, also due to their direct or indirect connections with peasants' leagues that were mostly composed by caboclos and afro-descendants (Ferretti 2020).

In the first part of my paper, I discuss the grounds of geographers' commitment to programmes of regional planning in the formation of Northeastern scholarly networks, associated with the very notion of 'active geography'. In the second part, I analyse the results of their collective survey of the river basins where sugarcane monoculture occurred with the related social and environmental problems. In the third part, I analyse the critiques and commitment of geographers, especially Josué de Castro, to the SUDENE and its leader Celso Furtado.

\section{Networking for geography and planning}

The notion of 'active geography' has been brought to the attention of English-speaking publics thanks to the translation of the Manifesto for the 'Active Role of Geography' by Milton Santos and his collaborators (Bernardes et al. 2017). This text is a classic of Brazilian critical geography, being still considered, by the members of the LABOPLAN laboratory at the University of São Paulo (USP), as something that found its roots in the Northeast in association with planning practices. ${ }^{2}$ The label géographie active was launched in the 1960 s by a group of

\footnotetext{
${ }^{1}$ Recife, Fundação Joaquim Nabuco,Coordenação-Geral de Estudos da História Brasileira (hereafter CEHIBRA) 5, Jornal do Comércio, 12 December 1960. All quotes from texts in French or Portuguese have been translated by the author.

2 'Debate com Milton Santos', 2000 https://www.youtube.com/watch?v=xpM6M08rI3E

F. Ferretti, 2021, "Decolonizing regional planning from the Global South: active geographies and social struggles in North-eastern Brazil", Environment and Planning D - Society and Space, early view https://journals.sagepub.com/doi/full/10.1177/02637758211024647
} 
left/wing French geographers led by Pierre George (1909-2006) and including Yves Lacoste, Raymond Guglielmo (1923-2011) and Bernard Kayser (1926-2001), most of whom were acquainted with Santos, Castro and Andrade (Ferretti 2018 and 2019b). For George, geography should be 'active and propositional' (George 1964, 34) to illuminate administrative action. I use the definition of 'active geography' as a synonymous with political and socially engaged (thus relevant) geography, as Milton Santos and his friends intended it. Therefore, this notion can be associated with that of socially transformative planning.

Kayser argued that the key unit for geographers' social commitment was the region, to be no longer considered as an historical or natural object like in the classical French tradition, but as a dynamic economic space that should be planned and transformed. Kayser expressed interest in the theory of growth poles (Rossi 2019) inspired by the 'school of F[rançois] Perroux' (Kayser 1964, 307), a French economist who was likewise an acquaintance of Castro, Santos and Furtado. As a geographer, Kayser significantly called for a collaboration between geographers and economists in the context of regional planning. Later, Santos's Manifesto argued for the use of geographical knowledge, requested by 'all sorts of territorial planning proposals' (Bernardes et al. 2017, 953), to enhance geography's relevancy through "“systematic" interventions ... at different levels of political practice ... committed to the transformation of society' (Bernardes et al. 2017, 956). Therefore, these Brazilian geographers relied on their 'French connection' but proposed original and internationally influential interpretations.

Urban and regional issues were among the first concerns of Pernambucan geographers since the 1930s, when Castro started studying the mocambos, informal settlements of Afro-Brazilian origin made of self-constructed houses, in wood and mud, which filled Recife's popular neighbourhoods. Considered as a social problem, these settlements were periodically threatened with evictions against which Castro publicly campaigned, ${ }^{3}$ arguing that mocambos were much more fit for Recife's climates and the environing 'mesological conditions' (Castro $1937,72)$ than the metal barracks envisaged by the building speculation at their place. For

\footnotetext{
${ }^{3}$ CEHIBRA, JCo, 349, Um higienista defende os mucambos de Recife contra a picareta official, $A$ Tarde, 23 November 1938 .

F. Ferretti, 2021, "Decolonizing regional planning from the Global South: active geographies and social struggles in North-eastern Brazil", Environment and Planning D - Society and Space, early view https://journals.sagepub.com/doi/full/10.1177/02637758211024647
} 
Castro, the agency of marginalised communities such as Mocambo settlers should be the drive and not the impediment of urban and regional plans. Widely shared among Northeastern geographers, Castro's position was a far cry from mainstream ideas of Brazilian white elites about planning intended as 'hygienisation' and 'attuned to colonialist legacies of racism and class stigma' (Garmany and Richmond 2020, 126), leading to the destruction of lower class neighbourhoods under pretexts of public health and 'security'. As Archie Davies notes, what Castro challenged in Recife were public policies of aterramento (that is, 'making land'). These policies reflected 'an absorptive and eradicative notion of whiteness that necessitated the creation of dry, enclosed land' (Davies 2020,1) to foster 'modernity' by 'sanitising' the amphibious environment of the mocambos, which were situated in the estuarine mangroves of the Capibaribe and Beberibe rivers and whose dwellers were socially and racially stigmatised (Davies 2021; Ferretti 2020).

In the 1950s, Louis-Joseph Lebret (1897-1966), a left/wing Dominican priest and Castro's friend, was appointed by the CODEPE (Comissão de Desenvolvimento Econômico de Pernambuco), in which Correia de Andrade was concurrently involved, ${ }^{4}$ to write an early proposal for regional planning in the Northeast (Lebret 1955). Lebret's journal Economie et Humanisme was explicitly endorsed by Kayser as a reference for active geographies (Kayser 1964). Concurrently, geographer Mauro Mota observed how Recife was 'swelling up' instead of 'growing' due to a lack of planning (Mota 1958). For this phenomenon, Lacerda de Melo had launched the definition of Mocambopolis (Melo 1940), inserting this problem in the context of migration from the hinterland regions due to the periodic droughts that affected the sertão (Melo et al. 1961). Mota and colleagues protested ideas that these droughts were a mere 'natural' flaw, requesting public interventions including 'expropriation' (Mota 1958, 134). Implicitly recalling Geddes' model of the Valley Section, Castro authored a monograph on Recife based on the metaphor of the region and the city as parts of 'the same living organism' (Castro 1959, 219). This reveals a general orientation of Pernambucan geographers in considering urban problems as strictly associated with matters of regional planning, and poverty as not a 'natural' phenomenon, but an effect of bad social and territorial organisation.

\footnotetext{
${ }^{4}$ MCA-RS1950-0141, Souza Barros to Correia de Andrade, 13 December 1954.

F. Ferretti, 2021, "Decolonizing regional planning from the Global South: active geographies and social struggles in North-eastern Brazil", Environment and Planning D - Society and Space, early view https://journals.sagepub.com/doi/full/10.1177/02637758211024647
} 
In the same years, in Salvador da Bahia, Milton Santos co-founded the Laboratory of Geomorphology and Regional Studies, likewise committed to regional planning for the purposes of social change. A brochure that he published in 1959, A cidade como centro da região, echoed Castro's arguments by arguing that 'city and region are mutually interdependent' (Santos 1959, 9). While Santos is a famous figure, one which is the object of numerous studies (Contel 2014; Davies 2019a; Ferretti and Pedrosa 2018; Melgaço 2017), his collaboration with Pernambucan geographers during those years is less known. His unpublished archives can shed some light on his important role in connecting geographers from Salvador and Recife. His letters to Correia de Andrade account for Santos' direct collaboration with 'the Pernambucan geographical family'.5 A pivotal figure in this 'family' was Mota, defined by Santos and Andrade as 'our common friend'. ${ }^{6}$ In January 1958, Santos wrote that Mota had invited him to Recife for 'a conference and fieldwork with Gilberto [Osório] and you. [However], it would be difficult for me if the fieldwork is long' ${ }^{7}$ This correspondence reveals that, albeit he could not directly contribute due to other commitments, Santos was one of the scholars potentially involved in the investigation of the Northeastern Rios-de-açucar [Sugar Rivers], a major endeavour of Recife geographers.

Led by Correia de Andrade and Osório de Andrade, this project was funded by the Nabuco Institute, now Fundação Joaquim Nabuco, a cultural institution dedicated to famous Pernambucan abolitionist Joaquim Nabuco (1849-1910), thanks to Mota, who directed the institute. Osório was then the Chair of Physical Geography at the Federal University of Pernambuco. In 1952, early-career Correia de Andrade was appointed an assistant to this Chair ${ }^{8}$ and both geographers, in collaboration with the Chair of Human Geography, Mário Lacerda, worked to reach a stronger national and international impact for Pernambucan geography. To achieve this goal, they attended the 1956 Congress of the International Geographical Union in Rio de Janeiro, considered an important landmark in the construction of an original 'Brazilian Geography' (Vargas and Bomfim 2014), and took leading roles in the Association of Brazilian Geographers (AGB) (Araújo 2002, 105). While Correia had political divergencies with Osório,

\footnotetext{
${ }^{5}$ São Paulo, Instituto de Estudos Brasilieros (hereafter IEB), MCA-RS1950-0210, Santos to Correia de Andrade, 9 August 1958.

${ }^{6}$ IEB, MCA Caixa 36 (provisional inventory), Santos to Correia de Andrade, 11 March 1960.

${ }^{7}$ IEB, MCA-RS1950-0172, Santos to Correia de Andrade, 14 January 1958.

${ }^{8}$ IEB, MCA-RS1950-0025, Rabello to Correia de Andrade, 15 April 1952.
}

F. Ferretti, 2021, "Decolonizing regional planning from the Global South: active geographies and social struggles in North-eastern Brazil", Environment and Planning D - Society and Space, early view https://journals.sagepub.com/doi/full/10.1177/02637758211024647 
whom he deemed too conservative, they worked together from 1957 to 1959 in the 'Sugar Rivers' investigation to state the 'unity of [human and physical] geography' (Araújo 2002, 106) to resolve practical problems.

Concurrently, Correia's PhD dissertation on the River Siriji's valley, in Pernambuco, was saluted by his São Paulo correspondent and mentor Caio Prado Júnior, one of the most prestigious Leftist intellectuals in Brazil and co-founder of the AGB (Heidemann, Iumatti and Seabra 2008). Prado focused on the relevancy of geography: 'If only we had similar works about all [Brazil's] regions ... A lot of economic problems would be easily resolved'. ${ }^{9}$ The 'sugar rivers' project was performed by applying the theoretical framework of the river basin to define regional units, and it was aimed at discovering causes and possible remediations to an issue for which geographical investigation was a pioneering endeavour at that time: the pollution of rivers by the sugarcane industry. While this project extended a local tradition of regional planning, especially in the region of the São Francisco River, inspired by 'Northern' experiences such as the Tennessee Valley Authority (Buckley 2017), it raised social and economic issues, clashing with the traditionally strongest powers in Brazilian Northeast: latifundium and political corruption.

From 1957 to 1959, Osório de Andrade and Correia de Andrade directed a team of a dozen students and researchers, including Rachel Caldas Lins, the author of several works on the Northeastern countryside, ${ }^{10}$ and Mario Lacerda (Osório de Andrade 1957), who worked in the valleys of the rivers Ceará-Mirim (Rio Grande do Norte), Mamanguape and Paraíba do Norte (Paraíba), Coruripe, Jiquiá and São Miguel (Alagoas). There, they performed a detailed physical and social survey (including cartographic and photographic documentation), analysing the geomorphology of those valleys and sleeping in the local engenhos (farms that produce sugar), where they could interview residents. Some ironic remarks from Correia de Andrade's recollections reveal both the revolutionary potential of this study and the contradictions limiting its effectiveness. As for its subversive aspects, this was the first scientific survey to shed light on the environmental disasters produced by the planters, who

\footnotetext{
${ }^{9}$ IEB, MCA-RS1950-0082, Prado to Correia de Andrade, 8 November 1959.

${ }^{10}$ CEHIBRA, MMo, CRp33 doc.764,1, Lins to Mota, 9 July 1958; PIp30 doc312, Lins and Osório de Andrade, Diferentes combinações do meio natural na zona da mata nordestina, 1960 [report].
}

F. Ferretti, 2021, "Decolonizing regional planning from the Global South: active geographies and social struggles in North-eastern Brazil", Environment and Planning D - Society and Space, early view https://journals.sagepub.com/doi/full/10.1177/02637758211024647 
indiscriminately threw the derrames (effluents) of sugar and alcohol production processes, compromising the ecosystems of entire rivers with heavy repercussions for local populations. Thus, this research was potentially prickly for local speculators, who were opposed to all projects and reforms susceptible of engaging their privileges (Buckley 2017; Furtado 2014).

As for this programme's limitations, local masters were convinced (not without reason) that these scholars did not have any power for sanctioning them or for imposing any intervention of the public powers in their properties. Even more ironically, Correia de Andrade was the son of a dono de engenho, that is, a planter like them, so that the group was welcomed in the farms with all courtesies, and some of their hosts were almost proud to show them the pollution they had produced. 'It was amazing: we arrived, and we were sheltered in the master's houses. [There we were] princely welcomed, including with Scotch Whiskey, good French wine and polite conversation. They let us see everything. They did not make any problem because they knew that nothing would have happened' (Araújo 2002, 106). These ironic Andrade's acknowledgements of his own positionality are an example of the social and racial ambivalences of these radical Northeastern intellectuals as discussed above. However, this study was rich in consequences for Brazilian planning practices, as I explain below.

\section{Sweet regional surveys: geographers and sugar rivers}

Of the four volumes that resulted from this survey, the first and third were authored by Osório de Andrade, and the second and fourth by Correia de Andrade, although they can all be considered as collective works. First presented as reports to the Nabuco Institute, all the volumes were opened by dedications to Mota, explaining that the aim of these expeditions was to assess the 'damages created by the dispersion of sugar mills waste' (Osório de Andrade 1957a, 5). While these reports start with a geomorphological analysis to address then 'human' matters, in the tradition of classical European geography, an important characteristic of the Sugar Rivers project was its authors' interest in the colonial history of these regions and their cultural specificities. It is not coincidence that the members of the first expedition, which took place in the state of Rio Grande do Norte, went first to see Luís da Câmara Cascudo (18981986).

F. Ferretti, 2021, "Decolonizing regional planning from the Global South: active geographies and social struggles in North-eastern Brazil", Environment and Planning D - Society and Space, early view https://journals.sagepub.com/doi/full/10.1177/02637758211024647 
A friend and correspondent of Mota and Castro, ${ }^{11}$ Cascudo was one of the most eminent scholars of Northeastern popular culture and Afro-Brazilian communities. He collaborated with the research team in defining the historical peculiarities of Rio Grande do Norte in colonial times, when there has been less concentration of traditional engenhos than in Pernambuco, due to the relative scarcity of the slave workforce that was the pillar of the plantation economy first established by the Portuguese (Furtado 1963). According to Cascudo, the limited amount of slave labour made the region 'more receptive' (Osório 1957, 29) to the abolitionist campaign in the nineteenth century. The interest of these surveyors in racial and historical issues shows how their work was sensitive to matters on social reforms, which are strictly associated with indigenous and Afro-Brazilian insurgent histories (Porto-Gonçalves and Araújo-Quental 2012). Importantly, this approach broke with the racialised discourses and claims for 'whitening' local populations which characterises former planners' works in the Northeast (Buckley 2017).

The surveyors tried to define the 'mesological conditions' and 'ecological peculiarities' (Osório de Andrade 1957, 9) of each of these river basins, often divided into the 'high, medium and low valley' (Osório de Andrade 1957, 40). This implies that no external recipes for 'development' could be obtained without a careful study of all local (social and environmental) conditions. In the Ceará-Mirim valley, the problem of pollution was defined as especially serious in the geographers' report: 'The phenomena of putrescence, fishes' mortality and more biological and sanitary evils are the same as in all sugarcane-producing Northeast .... The concentration of wasted liquids in the Agua Azul River makes this water inappropriate for irrigation. [This river's] fauna is periodically devastated' (Osório de Andrade 1957, 55). Albeit the planters were sure of their impunity, these reports published the names of the polluting establishments producing sugar and cane alcohol.

In the second volume, studying the valley of the River Mamanguape, Correia de Andrade likewise did a geo-historical study of the region defined by this river basin. It is worth noting that the physical geography of Northeastern regions such as Pernambuco and Paraíba is characterized by a wet coastal strip called Mata Atlântica (Atlantic Rainforest), where the

\footnotetext{
${ }^{11}$ Natal (RN), Ludovicus, Instituto Câmara Cascudo. Castro, Mota and Osório de Andrade folders.
}

F. Ferretti, 2021, "Decolonizing regional planning from the Global South: active geographies and social struggles in North-eastern Brazil", Environment and Planning D - Society and Space, early view https://journals.sagepub.com/doi/full/10.1177/02637758211024647 
cultivation of sugarcane was traditionally established, and a transition area between the coast and the arid Sertão called Agreste (Rough Land). Anticipating the anticolonial claims of his classical works A Terra e o Homem do Nordeste (1963) and A Guerra dos Cabanos (1965), Andrade denounced the 'true devastation' (Correia de Andrade 1957, 26) that early forests suffered since the times of the Conquest, when the Portuguese started clearing woods to sell timber. Later, when the sugarcane economy was established, 'the forest's destruction was almost total' (Correia de Andrade 1957, 34). Correia denounced the long-term environmental consequences of this colonial history and criticized the regime of monoculture, matching arguments from Castro's famous Geography of Hunger (1946) in favour of the cultivation of different crops for the subsistence of local people. Sugarcane labourers suffered 'hard blows' (Correia de Andrade 1957, 41) because monoculture determined a condition of misery that these geographers considered to be due to latifundium and social injustice, rather than to an alleged 'natural poverty' of the region. Finally, the report denounced the 'sanitary, alimentary and economic' (Correia de Andrade 1957, 55) problems entailed by diverse kinds of sugar waste, generally called caldas (liquids), including the unavailability of drinking water for the communities living over the river, concluding that the main problem was the need for a different social and economic organization.

In the third report, on the Paraíba Norte River valley, Osório discussed problems associated with water management, quoting the notion of 'vindictive resurrections' (Osório de Andrade $1959,24)$ by Mauro Mota. This was a way to define the floods that devastated the coastal areas after the droughts that periodically affected the sertão. Again, Osório analysed the colonial history of sugarcane production, observing that, in the state of Paraíba, the indigenous slave workforce was preferred for some time to the African one. Unlike Correia, Osório used some seemingly despising terms for indigenous populations, but he could not refrain from noticing the intrepidity of the history of 'Indian rebels' (Osório de Andrade 1959, 81) during the colonial period and from condemning the 'pretext' (Osório de Andrade 1959, 96) of evangelization alleged by early colonizers to capture slaves, who died massively in the plantations. For Osório, a historic characteristic of Paraíba was an overall lower rate of the slave population, that is, according to statistics quoted from Caio Prado Júnior, no more than $15-16 \%$ in relation to $30 \%$ on a national basis for the early nineteenth century (Osório de Andrade 1959, 101). Referencing

F. Ferretti, 2021, "Decolonizing regional planning from the Global South: active geographies and social struggles in North-eastern Brazil", Environment and Planning D - Society and Space, early view https://journals.sagepub.com/doi/full/10.1177/02637758211024647 
Cascudo, Osório argued that this was due to the early presence of a cultivation alternative to and competing with sugarcane, that is, cotton, which was seen as 'more democratic' (Osório de Andrade 1959, 101) than sugarcane because it favoured the creation of a rural middle class. This was deemed a step towards 'emancipation' (Osório de Andrade 1959, 125) from the almost-feudal system of sugar mills. The 'dirtying' (Osório de Andrade 1959, 141) of flowing waters and related problems affecting local societies and their 'ecological equilibrium' (Osório de Andrade 1959, 143) were once more denounced and documented. Again, the ambivalence of members of white elites dealing with marginalised communities did not impede that even the most conservative member of the expedition, Osório, felt some proximity with the subaltern histories of his land, Northeastern Brazil.

The last volume, authored by Correia de Andrade with the assistance, among others, of Rachel Caldas Lins who was 'designed for the direction of the Human Geography section of [the Nabuco] Institute' (Correia de Andrade 1959, 6), addressed the hydrographic network of the small state of Alagoas. It was explicitly informative regarding the principle of the 'regional study of river basins' (Correia de Andrade 1959, 10), where the regionalisation of geographers and planners does not necessarily match administrative units (Correia de Andrade 1959, 23). Again, the colonial history of the region was raised, anticipating themes that inform current decolonial literature: Alagoas was home to the most famous and currently valued Brazilian experience of indigenous and Black insurgency, that is, the quilombo (community of fugitive slaves) of Palmares established in the seventieth century and led by the legendary figure of Zumbi (Schwarcz and Gomes 2018). Correia de Andrade, a protagonist in the rediscovery of insurgent histories from subaltern communities in in Brazil (Ferretti 2019a), lamented the destruction of Palmares 'by the Paulistas' (Correia de Andrade 1959, 37), which allowed the definitive establishment of the latifundium plantation system in this unruly region.

Stressing the continuity between colonial histories and the reality of his days, Andrade denounced the 'predatory and anti-economical' (Correia de Andrade 1959, 52) practices of destroying the forest, coming back to the need for protecting small-scale subsistence agriculture and breeding as necessary for the workers' food supply. Alagoas was also the place of early attempts to establish cooperatives as an alternative to latifundium and workers' exploitation

F. Ferretti, 2021, "Decolonizing regional planning from the Global South: active geographies and social struggles in North-eastern Brazil", Environment and Planning D - Society and Space, early view https://journals.sagepub.com/doi/full/10.1177/02637758211024647 
since the 1930s. Correia de Andrade was a supporter of cooperative solutions for the Northeast, this time against the views of his friend Caio Prado, who was instead a supporter of the establishment of small rural properties. ${ }^{12}$ The geographer had to admit the failure of cooperatives, albeit arguing that they should have been resumed as an alternative to the disastrous social situation that he witnessed during the survey. Sugarcane labourers were substantially divided into two categories: operários (workers), protected by some 'labour legislation' (Correia de Andrade 1959, 75) in the workshops, and moradores (dwellers) in traditional farms, who were subject to all form of planters' arbitrary power.

Arguing for the need for a deeper knowledge of territories and of their colonial histories and social realities, and based on the notion of river valley as the place for the regional survey, these geographers pioneered environmental concerns against the predation of natural resources, claiming the social and political relevancy of their discipline in association with planning. While their collective conclusions seemed politically moderate, Correia de Andrade was clearly the most radical in the group (Ferretti 2019b) and would be arrested in 1964 at the beginning of the military dictatorship, which eventually put an end to these reformistic endeavours (Araújo 2002, 116). In 1963, A Terra e o Homem was published with the explicit purpose of 'serving the needs of the agrarian reform' (Araújo 2002, 109), in the same year of the biggest strike of Northeastern sugarcane labourers (Rogers 2010), organized by peasant leagues that were supported by Andrade and Castro. As I explain in the next section, the contribution of these geographers to the Operation Northeast - SUDENE, trying to reform society 'through a better planning, ${ }^{13}$ needs to be rediscovered, for the insights that this can provide towards decolonizing planning theories and practices 'from the South'.

\section{Critical planning in the Northeast}

The history of the SUDENE, instituted in 1959 by Brazilian President Juscelino Kubitschek (1902-1976) to foster social development in the Northeast, is narrated in recollections of its early leader Celso Furtado, an economist whose works have long been discarded in international scholarship under the label of 'structuralism', which typically accompanied the

12 IEB, CPJ-CP-AND001, Correia de Andrade to Prado, 24 February 1945.

${ }^{13}$ IEB, MCA-GPE 0011, O drama da seca [n.d.].

F. Ferretti, 2021, "Decolonizing regional planning from the Global South: active geographies and social struggles in North-eastern Brazil", Environment and Planning D - Society and Space, early view https://journals.sagepub.com/doi/full/10.1177/02637758211024647 
neglect of dependency theories (Slater 2004). However, some aspects of Furtado's output are rediscovered in current scholarship, including the idea of 'assigning culture a pivotal role' (Cunha and Britto 2018, 177) in development programmes. Thus, Furtado's use of ideas on 'creativity' drew on technics but also on the mobilization of 'non-material culture, in the form of social organizations, science, art, philosophy, music, religion, morality, customs and other forms of social heritage' (Cunha and Britto 2018, 190).

Economists are reassessing the figure of Furtado as one of 'these important pioneers of the developmentalist perspective' (Seccareccia and Correa 2014, 3), highlighting the originality of his thinking, which took insights from authors such as Marx, Keynes, Schumpeter, Myrdal and Perroux but cannot be labelled under a singular definition. This confirms my argument about the capacity of Northeastern scholars of elaborating original models considering cultures and colonial histories of their land. In this section, I show how the contribution of geographers to these 'heroic' years of Operation Northeast, albeit never uncritical of Furtado and his apparatus, was more substantial than what has been believed hitherto, until the 1964 coup came to interrupt this experience.

Despite its later reputation as a place for corruption and clientelism, SUDENE played a disruptive role in the context of Northeastern society until the end of Furtado's mandate (Andrade 2000). Furtado claimed that this institution remained extraneous to corruption and irregularities under his lead, despite the pressures of local elites hoping for the opening of a new 'faucet' (Furtado 2014, 275) from which to capture public money. A member of Brazilian expeditionary corps in Europe at the end of World War Second, Furtado had the occasion to complete his studies in post-war Paris, where he attended the courses of Perroux (Furtado 2014, 41) before joining the newly founded United Nations agency for Latin America, the CEPAL. There, debates on growth poles and dependency theory took place, also inspired by Argentinian economist Raúl Prebisch (1901-1986), who was Furtado's boss in the CEPAL headquarters in Santiago, Chile. While the key question for CEPAL intellectuals was to understand "what a plan for development can look like' (Furtado 2014, 136), it was in these years that Furtado started to reflect on the historical continuity of colonial relations and on the examples of radical insurgency that were well represented in Chile, 'the American Latin country where indigenous

F. Ferretti, 2021, "Decolonizing regional planning from the Global South: active geographies and social struggles in North-eastern Brazil", Environment and Planning D - Society and Space, early view https://journals.sagepub.com/doi/full/10.1177/02637758211024647 
population opposed most resistance to European invaders' (Furtado 2014, 73). This inspired his idea of considering Brazilian economy, based on the export of raw materials, not as 'peripheral' but as 'colonial' (Furtado 2014, 76), which chimes again with later MCD arguments. Proud of his origins in the sertão, Furtado paid special attention to historical and geographical contexts of economic phenomena, especially in his classical book Formação Económica do Brasil, written between 1957 and 1958 (Furtado 2014).

A sociologist who was very interested in Furtado's ideas and likewise an exponent of dependency theories, Fernando Henrique Cardoso, worked at the CEPAL offices in Santiago in the mid-1960s, when he was compelled as well to quit the country for some years under the dictatorship. Although a figure of the Brazilian Left, Cardoso claimed that, in those years, he was politically more 'moderate' (Sorj et al. 2011, 170) than Furtado, and used so successfully his 'pragmatism' (Sorj et al. 2011, 169) that after the end of the dictatorship he managed to become the President of Brazil in the 1990s. In this capacity, he was often criticised by his former comrades for favouring privatisations, although he continued to claim the 'neosocialist' (Sorj et al. 2011, 185) nature of his politics. This further highlights the radical nature of the endeavours of North-eastern scholars such as Furtado, who was less keen to accept compromises than many of his fellows in the political opposition.

In accepting Kubitschek's invitation to establish the SUDENE, Furtado aimed at elaborating 'a comprehensive plan of action, built upon regional planning techniques' (Furtado 2014, 266). Furtado's public speech to launch 'Operation Northeast' immediately triggered a violent mobilization of conservative forces in the Brazilian press, charging Furtado and his friends with 'communist plots' and arguing that they were a danger to 'national security'. The powerful conservative publisher Assis Chateaubriand (likewise a harsh adversary of Castro) called Furtado a 'Conselheiro in evening dress' (Furtado 2009, 19), with reference to the story of Antônio Conselheiro (1830-1897), a mystic who led the historical peasant revolt of Canudos, a sertão locality between Bahia and Pernambuco, whose residents were massacred by the Brazilian army in 1897 as famously narrated by Euclides da Cunha (Hecht 2013).

F. Ferretti, 2021, "Decolonizing regional planning from the Global South: active geographies and social struggles in North-eastern Brazil", Environment and Planning D - Society and Space, early view https://journals.sagepub.com/doi/full/10.1177/02637758211024647 
In his report, Furtado highlighted the 'dependency relations' (Furtado 2009, 32) of Northeastern economy, to be resolved by ending 'latifundium, monoculture and concentration of wealth' (Furtado 2009, 38). Importantly, this renovation should not come from universalist recipes, but from thorough studies such as those that were then ongoing on the Sugar Rivers, considering the mesological conditions of the region to stop the 'divorce between man [sic] and environment' (Furtado 2009, 43). This would have allowed the creation of a specific economy of the sertão, one which could also resist the periodic droughts by 'taking much more seriously the studies on the hydrological cycle' (Furtado 2014, 318). Furtado also advocated the creation of cooperatives through land 'expropriation by the state' (Furtado 2009, 65).

This report was the occasion for a public debate between Furtado and Castro, the latter being one of the strongest supporters of Northeastern peasants' leagues (Davies, 2019b), and a friend of their historical leader Francisco Julião (1915-1999). Likewise exiled after the 1964 coup, eventually in Mexico, where he met Correia de Andrade in $1969,{ }^{14}$ Julião corresponded with Castro, as shown by his archives in Recife. In his letters to Julião, Castro, who was then a parliament member, offered help to raise funds for the peasants' cause, expressing his admiration for Julião's activities in Pernambuco. ${ }^{15}$ On the occasion of the 1958 congress of the peasants' leagues in Recife, Castro offered help for the delegates' transportation with trains and buses, announcing that he was travelling 'to Fortaleza' ${ }^{16}$ but he would come back in a timely manner to attend the congress. Importantly, among his numerous endorsements to the leagues, ${ }^{17}$ Castro wrote to Julião requesting materials for his key book Death in the Northeast, when he was in Geneva as the Brazilian ambassador at the United Nations. ${ }^{18}$ Given these premises, it is not surprising that Castro was a key interlocutor for Furtado's project and that he started to write reports as an assessor for the Operação Nordeste since $1958 .{ }^{19}$

As discussed by Davies, Furtado's first report left Castro with several perplexities, albeit there were enough convergences between their respective ideas to claim a fuller insertion of Castro's

\footnotetext{
${ }^{14}$ CEHIBRA, FJ DPt1, Correia de Andrade, Chico Julião.

${ }^{15}$ CEHIBRA, FJ CRp1 doc 2,1, Castro to Julião, 25 March 1958.

${ }^{16}$ CEHIBRA, FJ CRp1 doc 3, Castro to Julião, 08 May 1958.

${ }^{17}$ CEHIBRA, FJ CRp1 doc 5, Castro to Julião, 19 April 1961.

${ }^{18}$ CEHIBRA, FJ CRp1 doc 6, Castro to Julião, 04 January 1964.

${ }^{19}$ CEHIBRA, jdC, 309, Castro, Operação Nordeste, 1958 [typewritten report].
}

F. Ferretti, 2021, "Decolonizing regional planning from the Global South: active geographies and social struggles in North-eastern Brazil", Environment and Planning D - Society and Space, early view https://journals.sagepub.com/doi/full/10.1177/02637758211024647 
work in histories of dependency theories (Davies 2019c). In a public debate hosted by the popular journal Observador Económico e Financeiro, ${ }^{20}$ Castro expressed three fundamental critiques of Furtado's text: first, he denied the problem of the sertão's overpopulation, which had led Furtado to hypothesize the displacement of part of the Northeastern population to the state of Maranhão; second, he denied that the Northeast was intrinsically 'poor'; finally, he argued that the problem was not only to establish cultivations that are resistant to droughts, but to accomplish a full agrarian reform transforming the production structures. However, Castro defined Furtado's speech as 'magnificent'. ${ }^{21}$ While powerfully arguing against Malthusianism after his works on Geopolitics of Hunger (1951) and criticizing some technical aspects of the SUDENE project, Castro endorsed Furtado's attempts to transform Northeastern society using the instruments of regional planning. The main divergence between the two men was that Castro expressed more radical views such as the following: 'An agrarian reform is therefore absolutely necessary and indispensable', ${ }^{22}$ while on this point Furtado was more cautious.

The importance of Castro's involvement in this debate is confirmed by archival materials surviving at the CEHIBRA, such as parliamentary reports showing that the geographer participated in the approval process of the SUDENE, representing the 'Parliamentary Union of North and Northeast'. Thus, he may also be considered one of the co-founders of the SUDENE, or at least one of its inspirations. Immediately after his discussion with Furtado, on 21 May 1959, Castro presented a report mobilising decolonial arguments in favour of SUDENE and regional planning, to 'emancipate Brazil from its economy of colonial type'. ${ }^{23}$ Responding to other parliament members who criticised Furtado for his emphasis on industrialisation in a region considered to have an agricultural vocation, Castro defended the project, arguing that agriculture would have been the indispensable premise to industrialisation. This latter was necessary to correct the imbalance between the industrialized South of Brazil and the monoculture-based Northeast: Castro associated the notion of dependency with that of internal colonialism, key to current decolonial debates (Mignolo and Escobar 2010), defining the Northeast as 'a colony within its same country', which produced 'raw materials for the

${ }^{20}$ Castro and Furtado, 'Operação Nordeste: Dois nomes e duas opinões', Observador Economico e Financeiro, 278, April 1959.

${ }^{21}$ Castro and Furtado, 'Operação Nordeste', 29.

${ }^{22}$ Castro and Furtado, 'Operação Nordeste', 31.

${ }^{23}$ CEHIBRA, JCo, 705, Operação Nordeste [1959], 3.

F. Ferretti, 2021, "Decolonizing regional planning from the Global South: active geographies and social struggles in North-eastern Brazil", Environment and Planning D - Society and Space, early view https://journals.sagepub.com/doi/full/10.1177/02637758211024647 
enrichment of other areas of Brazil', ${ }^{24}$ as noted above. The idea of the Northeast as an internal colony is fundamental to understand the political relevance of these planning projects.

Importantly, Castro argued for the SUDENE as a possible remediation against the so-called 'drought industry', that is, the clientelist apparatus of the national plans for assisting the victims of Northeastern droughts and only benefited 'clever intermediaries'. ${ }^{25}$ The geographer appealed for the modification of 'the socio-economic reality of the region, its geo-economical peculiarities and its cultural structure', highlighting 'the imperative needs of planning' in the Northeast, to end with the 'colonial and feudal drama'26 resulting from dependency, monoculture and latifundium. This would imply the accomplishment of the agrarian reform requested by the peasants' leagues and by Castro, who called to 'unify' ${ }^{27}$ the struggles of students and peasants. These positions were consistent with Castro's parliamentary action, defending president Kubitschek from accusations of fostering excessive interventions in the economy, which Castro considered necessary to counter North-American liberalism, which he equated to 'a colonial economy'. ${ }^{28}$ While this 'economic dirigisme' was consistent with notions of national sovereignty and import-substitution industrialization, its centralism was one of the limitations of this planning policy, which did not survive the shock of the military dictatorship.

In the following years, Furtado and the newly instituted SUDENE suffered all kinds of accusations and calumniations from the conservative press, raging against the "communist danger' that would be one of the pretexts for the 1964 military coup. According to Furtado, milieus of the planters considered the 1963 SUDENE's Plan a sort of 'disguised agrarian reform' (Furtado 2014, 297), and they tirelessly fought against the project, which they deemed a conspiracy "to establish in the country a "communist regime", a "syndicalist republic", (Furtado 2014, 424). Correia de Andrade confirmed that, among local politicians, "there was a terrific campaign against Celso' (Araújo 2002, 111). Despite having his own critiques to the SUDENE, because 'more radical measures' (Correia de Andrade 1963, 233) were needed,

\footnotetext{
${ }^{24}$ CEHIBRA, JCo, 705, Operação Nordeste, 5.

${ }^{25}$ CEHIBRA, JCo, 705, Operação Nordeste, 6.

${ }^{26}$ CEHIBRA, JCo, 705, Operação Nordeste, 8-11.

${ }^{27}$ CEHIBRA, JCo, 5, 'Uma ajuda que não ajuda', Jornal do Comercio (Recife) 9 May 1961.

${ }^{28}$ CEHIBRA, JCo, 705, Dirigismo económico e nacionalismo [1957], 8.
}

F. Ferretti, 2021, "Decolonizing regional planning from the Global South: active geographies and social struggles in North-eastern Brazil", Environment and Planning D - Society and Space, early view https://journals.sagepub.com/doi/full/10.1177/02637758211024647 
Correia was another of Furtado's supporters claiming that, far from charges of clientelism, Furtado was the man who challenged 'the drought industry'. ${ }^{29}$

In the Brazilian press, among Furtado's defenders one finds again Castro, arguing against the programmes of foreign assistance and for the development of endogenous measures in which 'the SUDENE is our ally and it should be supported by all Northeastern people'. ${ }^{30}$ The geographer continued releasing parliamentary appeals to avoid that 'petty interests compromise the economic redemption of the Northeast'. ${ }^{31}$ For Castro, the Northeast Operation was the first great victory of the 'people's representatives' against 'colonial economy'. ${ }^{32}$ In a conference to the AGB, he stressed the need for implying 'professional geographers in the works of regional planning, ${ }^{33}$ and crucially endorsed the SUDENE's studies confirming that: 'The big evil of the Northeast is not the episodic phenomenon of the drought ... but the archaic and feudal structure of the agrarian property regime, which leads to the bad use of natural resources'. ${ }^{34}$ Thus, critical Brazilian geographers did not spare public support to the SUDENE, whose works countered classical deterministic arguments of poverty as a 'natural' flaw. Their support, however, was not uncritical and included (constructive) criticisms targeting more radical solutions.

Conversely, Furtado took some distance about 'mobilizing peasants, as Julião did' (Furtado 2014, 298), revealing that his idea of social change should occur rather 'from above' than 'from below'. He even led US senator Edward (Ted) Kennedy, to visit peasants' organizations, reporting how Kennedy was 'moved' (Furtado 2014, 372) by this visit. The Brazilian economist even collaborated with the North-American programme Alliance for Progress (Pinto and Gumiero 2018), albeit protesting against the foreign interferences that this implied. While these cautious approaches show how the allegations of Furtado leading 'communist plots' were simply invented, they did not impede the 1964 coup. Furtado was compelled to quit the country together with an impressive list of politicians, including Pernambuco's governor Miguel Arraes

\footnotetext{
${ }^{29}$ IEB, MCA-G-009, A terra e o homem no Nordeste hoje, Conferencia pronunciada o 15 de julho de 2003.

${ }^{30}$ CEHIBRA, JCo, 5 'Uma ajuda que não ajuda'.

${ }^{31}$ CEHIBRA JCo, 26, ‘Anistia aos insubmissos com o serviço militar’, Diario de São Paulo 19 March 1961.

${ }^{32}$ CEHIBRA, JCo, 27, 'O Prof. Josué de Castro considera Operação Nordeste grande vitória', Jornal do Comercio (Recife) 24 February 1959.

${ }^{33}$ CEHIBRA, JCo, 27, 'Fundamentos geográficos da Operação Nordeste', Correio da Manhã, 28 February 1959.

${ }^{34}$ CEHIBRA, JCo, 251, O Nordeste brasileiro [undated report, env. 1962].
}

F. Ferretti, 2021, "Decolonizing regional planning from the Global South: active geographies and social struggles in North-eastern Brazil", Environment and Planning D - Society and Space, early view https://journals.sagepub.com/doi/full/10.1177/02637758211024647 
de Alencar (1916-2005), three ex-presidents, and intellectuals such as Castro, Julião and Milton Santos. The SUDENE continued to exist under the military dictatorship, being progressively emptied of social and political contents (Andrade 2000). One of the reasons for this failure was doubtlessly the distance between these intellectual elites and grassroots movements. Northeastern people did not promote any effective resistance against the coup, and their political leaders did not request them to do so. This indecision between social change 'from below' and social change 'from above' has been previously discussed in scholarship on Castro (Ferretti 2019b). Yet, the idea of fostering scholars' participation starting from the South, and giving due attention to experiences which occurred in languages other than English and in places that are peripheral even for the 'periphery', is essential to reflect on decolonising geography and planning.

\section{Conclusion}

This paper has demonstrated the importance of rediscovering the neglected role of Brazilian critical geographers in fostering planning projects in the pre-dictatorship period. In their efforts to promote 'active geography', these engaged scholars pioneered Southern contributions to debates on development, dependency and environment by creatively re-elaborating ideas coming from the 'North'. Importantly, they proposed alternatives to neo-colonial recipes which included concerns for local cultures, histories and societies, showing an awareness of internal colonialism and of Afro-Brazilian and indigenous histories that anticipated some features of current decolonial ideas associating indigenous traditions with the establishment of societies that are just and more respectful of the environment (Rivera Cusicanqui 2019; Porto-Gonçalves and Araújo-Quental 2012). While the ambivalences of these members of local elites cannot be overlooked, it is likewise necessary to understand their complex positionalities in the peculiar context of the Northeast. These show how the South cannot be essentialised as a notion, and how their works should be understood through the notion of 'pluriversal' worlds, in which decolonial scholars and activists do not refuse everything that is European, but re-appropriate and re-elaborate critically plural ideas.

As discussed above, these geographers' networks were politically heterogeneous. Referring especially to current Latin-American literature on 'action from below' (Zibechi 2012; Stahler-

F. Ferretti, 2021, "Decolonizing regional planning from the Global South: active geographies and social struggles in North-eastern Brazil", Environment and Planning D - Society and Space, early view https://journals.sagepub.com/doi/full/10.1177/02637758211024647 
Sholk, Vanden and Becker 2014), one can argue that a limitation of these intellectual circuits was that of being too loosely linked to the grassroots movements and marginalised communities they sought to represent. While similar problems remains in contemporary Brazil, a country which is still characterised by striking social and racial contradictions and regional disparities, these geographers' endeavours remain an example of planning in the South and for the South by scholars who were acting in their own land, being connected with marginalised groups that shared their same language and culture. This provides material for current critical scholarship to reflect on issues such as the distance between the 'researcher' and the 'researched'. Studying these networks has demonstrated the effectiveness of considering activist practices alongside critical theory, paralleling the renewed interest for places and praxes in current scholarship on Latin American social movements (Souza 2016; Halvorsen, Fernandes and Torres 2019). The importance of rediscovering these experiences analysing works and archives that were mostly produced in languages other than English (Portuguese, but also French and Spanish) cannot be overstated if we want to engage decolonially and pluralistically with the aforementioned risks of Euro-centrism for the variegated fields of Southern thinking(s) and decolonial scholarship.

Finally, while 'decoloniality' cannot be equated with 'Southern Theory', what precedes allows for arguing that theories and practices 'from the South' (taken in their pluralities, complexities and possibly contradictions) can help decolonising knowledges and practices in geography, planning and critical scholarship in general. Despite contradictions and ambivalences, Northeastern geographers pioneered the radical use of 'quantitative' tools and planning for social purposes. This means engaging with marginalised groups and 'participation', but also endeavouring to provide critical insights, theoretical and practical, for social transformation, sitting in contrast with the political and economic powers in place. In this sense, planning can be decolonial, as one of the possible avenues for geographers to engage with society, and certainly as one of the preferred ways that were chosen by early critical Brazilian geographers. Unlike the traditional planning's complicity with Eurocentrism and (neo)colonialism, the case addressed here shows how disciplines that formerly served imperialism (such as geography and planning) can be pluralistic, anti-colonial, and based in some 'periphery'.

F. Ferretti, 2021, "Decolonizing regional planning from the Global South: active geographies and social struggles in North-eastern Brazil", Environment and Planning D - Society and Space, early view https://journals.sagepub.com/doi/full/10.1177/02637758211024647 


\section{Acknowledgements}

I have to first acknowledge the colleagues with whom I have continuing and fruitful discussions on Brazilian critical geographies, planning and the Northeast, especially Archie Davies, Breno Viotto Pedrosa, Fábio Betioli Contel, Guilherme Ribeiro and André Reyes Novaes. I also owe a lot to the great kindness of the archive officers at the CEHIBRA, especially Carlos Antonio Ramos de Carvalho and Sandra Melo Cavalcanti, and at the IEB, especially Elisabete Marin Ribas. Finally, I am especially thankful to the anonymous referees for EDP, who provided precious insights to improve my paper, and to the Editor, Alex Vasudevan.

\section{References}

Andrade MC (1957) Os rios-do-açúcar do nordeste oriental [hereafter RDA]. 2. O rio Mamanguape. Recife: IJNPS.

Andrade MC (1959) [RDA 4]. Os rios Coruripe, Jiquiá e São Miguel. Recife: IJNPS.

Andrade MC (1963) A terra e o homem no Nordeste. São Paulo: Editora Brasiliense.

Andrade MC (1965) A guerra dos Cabanos. Rio de Janeiro: Conquista.

Andrade MC (2000) Memória: o homem do Nordeste. Teoria e Debate 45: http://csbh.fpabramo.org.br/o-que-fazemos/editora/teoria-e-debate/edicoes-

anteriores/memoria-o-homem-do-nordeste-entrevista-com-

Andrade GO (1957) [RDA 1]. O Rio Ceará-Mirim. Recife: IJNPS.

Andrade GO (1959) [RDA 3]. O Rio Paraíba do Norte. Recife: IJNPS.

Araújo RCB (2002) O fio e a trama. Depoimento de Manuel Correia de Andrade. Recife: UFPE.

Bernardes A et al. (2017) The active role of geography: a manifesto. Antipode, 49(4):952-958. Buckley E (2017) Technocrats and the Politics of Drought and Development in Twentieth Century Brazil. Chapel Hill: University of Northern Carolina Press.

Bunge W (1988) Nuclear War Atlas. Oxford: Basil Blackwell.

Buttimer A (1974) Values in Geography. Washington: AAG Commission on College Geography.

Castro Jd (1937) Documentário do Nordeste. Rio de Janeiro: Editora José Olympio.

Castro Jd (1946) A Geografia da fome. Rio de Janeiro: O Cruzeiro.

Castro Jd (1951) Geopolítica da fome. Rio de Janeiro: Editora Casa do Estudante do Brasil.

F. Ferretti, 2021, "Decolonizing regional planning from the Global South: active geographies and social struggles in North-eastern Brazil", Environment and Planning D - Society and Space, early view https://journals.sagepub.com/doi/full/10.1177/02637758211024647 
Castro Jd (1959) Ensaios de geografia humana. São Paulo: Brasiliense [2 ${ }^{\text {nd }}$ edition].

Castro Jd (1967) Homens e caranguejos. São Paulo: Brasiliense.

Castro Jd (1969) Death in the Northeast. New York: Random House.

Connell R (2014) Using southern theory: Decolonizing social thought in theory, research and application. Planning Theory 13(2):210-223.

Contel FB (2014) Milton Santos. In: Secco L and Pericas LB (eds) Intérpretes do Brasil. São Paulo: Boitempo, pp. 393-409.

Cunha AM and G Britto (2018) When development meets culture: the contribution of Celso Furtado in the 1970s. Cambridge Journal of Economics 42:177-198.

Davies A (2019a) Milton Santos: The conceptual geographer and the philosophy of technics. Progress in Human Geography 43(3):584-591.

Davies A (2019b) Unwrapping the OXO Cube: Josué de Castro and the intellectual history of metabolism. Annals of the American Association of Geographers 109(3):837-856.

Davies A (2019c) Josué de Castro 's Geografia Combatente and the political ecology of hunger. $\mathrm{PhD}$ thesis. London: KCL.

Davies A (2020) The racial division of nature: Making land in Recife. Transactions of the Institute of British Geographers early view: https://doi.org/10.1111/tran.12426

Davies A (2021) Landscape semaphore: Seeing mud and mangroves in the Brazilian Northeast. Transactions of the Institute of British Geographers early view: https://rgsibg.onlinelibrary.wiley.com/doi/10.1111/tran.12449

Esson J, Noxolo P, Baxter R, Daley P and M Byron (2017) The 2017 RGS-IBG chair's theme: decolonising geographical knowledges, or reproducing coloniality? Area 49(3):384-388.

Ferretti F (2018) Geographies of internationalism: radical development and critical geopolitics from the Northeast of Brazil. Political Geography 63:10-19.

Ferretti F (2019a) Decolonising the Northeast: subalterns, non-European heritages and radical geography in Pernambuco. Annals of the American Association of Geographers 109(5):16321650 .

Ferretti F (2019b) A coffin for Malthusianism: Josué de Castro's subaltern geopolitics. Geopolitics early view: https://www.tandfonline.com/doi/full/10.1080/14650045.2019.1583213

F. Ferretti, 2021, "Decolonizing regional planning from the Global South: active geographies and social struggles in North-eastern Brazil", Environment and Planning D - Society and Space, early view https://journals.sagepub.com/doi/full/10.1177/02637758211024647 
Ferretti F (2020)_From the drought to the mud: Rediscovering geopoetics and cultural hybridity from the Global South. cultural geographies 27(4):697-613.

Ferretti F and BV Pedrosa (2018) Inventing critical development: a Brazilian geographer and his Northern networks. Transactions of the Institute of British Geographers 43(4):703-717.

Fiddian-Qasmiyeh E and P Daley (2018) Routledge Handbook of South-South Relations. London: Routledge.

Furtado C (1963) The Economic Growth of Brazil. Berkeley: University of California Press. Furtado C (2009) O Nordeste e a saga da Sudene 1958-1964. Rio de Janeiro: Contraponto. Furtado C (2014) Obra autobiográfica (A fantasia organizada, a fantasia desfeita, os ares do mundo). São Paulo: Companhia das Letras.

Garmany J and MA Richmond (2020) Hygienisation, gentrification, and urban displacement in Brazil. Antipode 52(1):124-144.

George P (1964) Problèmes, doctrine et méthode. In George P, Guglielmo R, Kayser B and Y Lacoste, La géographie active. Paris, PUF, pp. 1-44.

Glasson J and T Marshall (2007) Regional Planning. London: Routledge.

Hecht SB (2013) The Scramble for the Amazon and the 'Lost Paradise' of Euclides da Cunha. Chicago: The University of Chicago Press.

Halvorsen S (2018) Decolonising territory: Dialogues with Latin American knowledges and grassroots strategies Progress in Human Geography, early view, doi: $10.1177 / 0309132518777623$

Halvorsen S, Fernandes BM and FV Torres (2019) Mobilizing territory: Socioterritorial movements in comparative perspective. Annals of the American Association of Geographers 109(5):1454-1470.

Heidemann HD, Iumatti P and M Seabra (2008) (eds.). Caio Prado Jr. e a Associação dos Geógrafsos Brasileiros. São Paulo: Edusp.

Jazeel T and Legg S. (Eds.) (2019). Subaltern Geographies. Athens: The University of Georgia Press.

Kayser B (1964) La géographie active de la région. In George P, Guglielmo R, Kayser B and Y Lacoste La géographie active. Paris: PUF, pp. 303-392.

Kothari, A., Salleh, A. Escobar, A., Demaria, F., Acosta, A. Pluriverse, a Post-development Dictionary. New Delhi, Tulika Books and Authorsupfront, 2019.

F. Ferretti, 2021, "Decolonizing regional planning from the Global South: active geographies and social struggles in North-eastern Brazil", Environment and Planning D - Society and Space, early view https://journals.sagepub.com/doi/full/10.1177/02637758211024647 
Lebret LJ (1955) Estudo sôbre desenvolvimento e implantação de indústrias, interessando a Pernambuco e ao Nordeste. Recife: CODEPE.

Melgaço L (2017) Thinking outside the bubble of the Global North: introducing Milton Santos and 'the active role of geography'. Antipode 49(4):946-951.

Melo ML (1940) Pernambuco, traços de sua geografia humana. Recife: Jornal do Comercio. Melo ML et al. (1961) As migracões para o Recife. Recife, IJNPS.

Mignolo W (2007) 'Coloniality of power and de-colonial thinking', Cultural Studies, 21(23):155-167.

Mignolo W and A Escobar (2010) (eds.) Globalization and the Decolonial Option. London: Routledge.

Mignolo W and C Walsh (2018) On Decoloniality: Concepts, Analytics, Praxis. Durham: Duke University Press.

Mota M (1958) Paisagem das secas. Recife: IJNPS.

Murrey A (2018) “"When spider webs unite they can tie up a lion”. Anti-racism, decolonial options and theories from the South'. In Fiddian-Qasmiyeh E and P Daley (2018) Routledge Handbook of South-South Relations. London: Routledge, pp. 59-75.

Noxolo P (2017) Decolonial theory in a time of the re-colonisation of UK research. Transactions of the Institute of British Geographers 42:342-344.

Pedrosa BV (2013) Entre as ruinas do muro: a história da geografia crítica sob a ótica da ideia de estrutura. PhD Dissertation. São Paulo: FFLCH/USP.

Pedrosa BV (2017) A recepção da teoria dos polos de crescimento no Brasil. Terra Brasilis 9: http://journals.openedition.org/terrabrasilis/2348

Pesce G (1981) (ed.) Da ieri a domani: la pianificazione organica di Kropotkin, Reclus, Branford e Geddes, Mumford. Bologna: Clueb.

Pinto GLH and RG Gumiero (2018) Auge y declive de las relaciones entre la SUDENE y la 'Alianza para el Progreso'. Revista CIDOB d'Afers Internacionals 120:73-94.

Porter L (2006) Planning in (post)colonial settings: Challenges for theory and practice. Planning Theory \& Practice 7(4):383-396

Porter L (2017) Indigenous people and the miserable failure of Australian planning. Planning Practice \& Research 32(5):556-570.

F. Ferretti, 2021, "Decolonizing regional planning from the Global South: active geographies and social struggles in North-eastern Brazil", Environment and Planning D - Society and Space, early view https://journals.sagepub.com/doi/full/10.1177/02637758211024647 
Porto-Gonçalves CW and P Araújo Quental (2012) Colonialidade do poder e os desafios da integração regional na América Latina Polis 31 http://polis.revues.org/3749

Power M (2019) Geopolitics and Development. Abingdon: Routledge.

Radcliffe, SA (2017) Decolonising geographical knowledges. Transactions of the Institute of British Geographers 42(3):329-333.

Rankin KN (2010) Reflexivity and post-colonial critique: Toward an ethics of accountability in planning praxis. Planning Theory 9(3):181-199.

Rivera CS (2019) Ch'ixinakax utxiwa: A reflection on the practices and discourses of decolonization. Language Culture and Society 1(1):106-119.

Rogers TD (2010) The Deepest Wounds: A Labor and Environmental History of Sugar in Northeast Brazil. Chapel Hill: University of North Carolina Press.

Rossi U (2019) Growth Poles, Growth Centers. In Kobayashi A (ed.) International Encyclopedia of Human Geography [2nd edition. Amsterdam: Elsevier [forthcoming].

Roy A (2006) Praxis in the time of empire. Planning Theory 5(1):7-29.

Roy A (2011) Urbanisms, Worlding Practices and the Theory of Planning. Planning Theory 10(1):6-15.

Sachs W (1992) ed. The Development Dictionary, a Guide to Knowledge as Power. London: Zed Books.

Santos M (1959) A cidade como centro de região. Definições e métodos de avaliação da centralidade. Salvador: Laboratório de Geomorfologia e Estudos Regionais.

Schwarcz LM and FS Gomes (2018) eds. Dicionário da escravidão e liberdade. São Paulo: Companhia das Letras.

Seccareccia M and E Correa (2014) Celso Furtado and Development Theory. International Journal of Political Economy 43(4):3-6.

Sidaway J, Woon CY, Jacobs J (2014) 'Planetary postcolonialism'. Singapore Journal of Tropical Geography 35:4-21

Slater D (1993) The geopolitical imagination and the enframing of development theory. Transactions of the Institute of British Geographers 18(4):419-437.

Slater D (2004) Geopolitics and the Post-colonial. Rethinking North-South Relations. Malden: Blackwell.

F. Ferretti, 2021, "Decolonizing regional planning from the Global South: active geographies and social struggles in North-eastern Brazil", Environment and Planning D - Society and Space, early view https://journals.sagepub.com/doi/full/10.1177/02637758211024647 
Sorj B, Fausto S, Thompson T and FH Cardoso (2011) The Sociologist and the Politician: An Interview with Fernando Henrique Cardoso, Latin American Perspectives 38(3):169-193.

Souza ML (2016) Lessons from praxis: Autonomy and spatiality in contemporary Latin American social movements. Antipode 48(5):1292-1316.

Stahler-Sholk R, Vanden H and M. Becker (2014) (eds.) Rethinking Latin American Social Movements: Radical Action from Below. London: Rowman \& Littlefield.

Vargas HM and PRA Bomfim (2014) La Geografía latinoamericana y la Unión Geográfica Internacional (UGI): los casos de Brasil (1956) y México (1966). Journal of Latin American Geography 13:215-232.

Winkler T (2018) Black Texts on white paper: Learning to see resistant texts as an approach towards decolonising planning. Planning Theory 17(4):588-604.

Winkler T and J Duminy (2016) Planning to change the world? Questioning the normative ethics of planning theories. Planning Theory 15(2):111-129.

Zibechi R (2012) Territories in Resistance: A Cartography of Latin American Social Movements. Edinburgh: AK Press.

F. Ferretti, 2021, "Decolonizing regional planning from the Global South: active geographies and social struggles in North-eastern Brazil", Environment and Planning D - Society and Space, early view https://journals.sagepub.com/doi/full/10.1177/02637758211024647 